\title{
Comparison GnRH agonist short protocol and GnRH antagonist in Brazilian normoresponder patients undergoing their first cycle of controlled ovarian stimulation
}

\author{
Comparação do protocolo curto do GnRH agonista e GnRH \\ antagonista em pacientes brasileiras normo-respondedoras \\ submetidas ao primeiro ciclo de estimulação ovariana controlada
}

Jalsi Tacon Arruda, Mário Silva Approbato, Mônica Canêdo Silva Maia, Tatiana Moreira da Silva, Carolina Rodrigues de Mendonça, Marisa de Sousa Ramos, Shirley Ribeiro Rodrigues, Maria Zélia Pires Brito, Coracy Coelho de Aguiar

Human Reproduction Laboratory; Clinical Hospital; Federal University of Goias, Goiania, Brazil. Competing interests: The authors report no financial or commercial conflicts of interest. Authors contributions: J.T.Arruda and M.S.Approbato were responsible for designing, coordinating the study, and for the statistical work. All authors were responsible for data collection, data analysis, and approved the final manuscript. J.T.Arruda was responsible for reviewing the manuscript and correspondences.

\begin{abstract}
Objective: to evaluate the results of gonadotropin-releasing hormone agonist (GnRH-ag) and gonadotropin-releasing hormone antagonist (GnRH-ant) using daily dose fixed of rFSH, in Brazilian normoresponder patients undergoing their first in vitro fertilization or intracytoplasmic sperm injection (IVF/ICSI) cycle.

Methods: a total 50 women were included in this retrospective comparative study. Patients were stimulated with standard $150 \mathrm{IU} /$ day recombinant FSH (follitropin alfa). In group GnRH-ag a daily dose of leuprolide acetate (1 mg short protocol) was administered starting on day 1 of the cycle till the day of hCG injection. In GnRH-ant group a daily dose of cetrorelix acetate $(0.25 \mathrm{mg})$ was administered when follicles reached a diameter of $\geq 14 \mathrm{~mm}$ Recombinant human chorionic gonadotropin $(250 \mu \mathrm{g}$ rhCG) was administered when at least three follicles of $18 \mathrm{~mm}$ in diameter were observed. Stimulation characteristics and outcome of both protocols were compared. Results: stimulation days with rFSH (11.0 vs. 9.24; $\mathrm{p}=0.0091)$, total doses of rFSH (2094 vs. $1365 \mathrm{IU}$; $\mathrm{p}<0.0001)$, GnRH using days ( 12.0 vs. 3.6; $p<0.0001)$, and total doses of GnRH ( 1.2 vs. $0.9 \mathrm{mg} ; p=0.0001$ ) was shorter in GnRH-antagonist group. The number of follicles $(\geq 16 \mathrm{~mm})$ on day rhCG ( 6.76 vs. $4.64 ; p=0.04)$ was higher in GnRH-ag group. There was no difference in the other parameters, nevertheless, the number oocytes retrieved (5.92 vs. $4.16 ; p=0.06$ ) was higher in $\mathrm{GnRH}$ -agonist group, but the fertilization rate (40.1 vs. 54.4 $\% ; p=0.29$ ) was higher in $\mathrm{GnRH}$-antagonist group. The rates of chemical and clinical pregnancy were similar in two groups.

Conclusion: controlled ovarian stimulation plays a major role in human reproduction and, it is well known that, even in normoresponders patients, the first treatment cycle exposes patients to a risk of either a low or an excessive ovarian response. In this study $\mathrm{GnRH}$-ag and $\mathrm{GnRH}$-ant provide comparable results, but antagonist protocol was shorter period of stimulation.
\end{abstract}

Keywords: GnRH agonist, GnRH antagonist, normal ovarian response, infertility.

\section{RESUMEN}

Objetivo: evaluar los resultados de la hormona liberadora de gonadotrofina agonista (GnRH-ag) y de la hormona liberadora de gonadotrofina antagonista (GnRH -ant), utilizando dosis diaria fija del FSH recombinante en pacientes normo-respondedoras brasileñas sometidas a su primer ciclo de fertilización in vitro o inyección intracitoplasmática de espermatozoides (FIV/ICSI).

Métodos: un total de 50 mujeres fueron incluidas en este estudio retrospectivo comparativo. Las pacientes fueron estimuladas con 150 UI/día de FSH recombinante (folitropina alfa). En el grupo GnRH-ag se administró una dosis diaria de acetato de leuprolida (protocolo corto $1 \mathrm{mg}$ ) a partir del día 1 del ciclo hasta el día de la inyección de hCG. En el grupo GnRH-ant se administró una dosis diaria de acetato de cetrorelix $(0,25 \mathrm{mg})$ cuando los folículos alcanzaron un diámetro de $\geq 14 \mathrm{~mm}$. Gonadotrofina coriónica humana recombinante $(250 \mu \mathrm{g}$ rhCG) fue administrada cuando se observaron al menos tres folículos de $18 \mathrm{~mm}$ de diámetro. Se compararon las características de estimulación y los resultados de ambos los protocolos.

Resultados: días de estimulación con FSH recombinante $(11,0$ vs. 9,$24 ; \mathrm{p}=0,0091)$, dosis total de FSH recombinante (2.094 vs. 1.365 UI; $p<0,0001)$, días usando GnRH $(12,0$ vs. 3,$6 ; p<0,0001)$, y las dosis totales del $\mathrm{GnRH}(1,2$ vs. $0,9 \mathrm{mg} ; \mathrm{p}=0,0001)$ fueron más cortas en el grupo antagonista de GnRH. El número de folículos ( $\geq$ $16 \mathrm{~mm})$ en el día del rhCG $(6,76$ vs. 4,$64 ; p=0,04)$ fue mayor en el grupo GnRH-ag. No hubo diferencias en los otros parámetros, sin embargo, el número de ovocitos recuperados $(5,92$ vs. 4,$16 ; p=0,06)$ fue mayor en el grupo de agonista de $\mathrm{GnRH}$, pero la tasa de fertilización $(40,1$ vs. $70,8 \% ; p=0,29)$ fue mayor en el grupo antagonista de $\mathrm{GnRH}$. Las tasas del embarazo químico o clínico fueron similares en ambos los grupos.

Conclusión: la estimulación ovariana controlada tiene un papel importante en la reproducción humana y, es bien sabido que, en pacientes normo-respondedoras, el primer ciclo de tratamiento expone las pacientes a un riesgo de ser una respuesta ovárica baja o excesiva. En este estudio $\mathrm{GnRH}$-ag y $\mathrm{GnRH}$-ant proporcionaran resul-
Recebido em 01-05-2013

Aceito em 01-09-2013
Copyright - Todos os direitos reservados a

SBRA - Sociedade Brasileira de Reprodução Assistida 
tados comparables, pero el protocolo antagonista fue más corto el período de estimulación.

Palabras-llave: agonista $\mathrm{GnRH}$, antagonista $\mathrm{GnRH}$, respuesta ovárica normal, infertilidad.

\section{RESUMO}

Objetivo: avaliar os resultados do agonista do hormônio liberador de gonadotrofinas ( $\mathrm{GnRH}-\mathrm{ag}$ ) e do antagonista do hormônio liberador de gonadotrofinas (GnRH-ant), utilizando dose diária fixa de FSH recombinante em pacientes brasileiras normo-respondedoras submetidas ao primeiro ciclo fertilização in vitro ou injeção intracitoplasmática de espermatozóides (FIV / ICSI).

Métodos: um total de 50 mulheres foram incluídas neste estudo retrospectivo comparativo. As pacientes foram estimuladas com $150 \mathrm{UI} /$ dia de FSH recombinante (folitropina alfa). No grupo de GnRH-ag foi administrada uma dose diária de acetato de leuprolide (protocolo curto $1 \mathrm{mg}$ ) desde o dia 1 do ciclo até ao dia da injeção de hCG. No grupo de GnRH-ant foi administrada uma dose diária de acetato de cetrorelix $(0,25 \mathrm{mg})$ quando os folículos atingiram um diâmetro de $\geq 14 \mathrm{~mm}$. Recombinante da gonadotrofina coriônica humana ( $250 \mu \mathrm{g}$ rhCG) foi administrada quando havia pelo menos três folículos de $18 \mathrm{~mm}$ de diâmetro. Foram comparadas as características da estimulação e os resultados de ambos os protocolos.

Resultados: dias de estimulação com FSH recombinante $(11,0$ vs. 9,$24 ; p=0,0091)$, dose total de FSH recombinante $(2,094$ vs. 1,365 UI; $p<0,0001)$, dias utilizando GnRH $(12,0$ vs. 3,$6 ; p<0,0001)$, e dose total de $\mathrm{GnRH}$ $(1,2$ vs. $0,9 \mathrm{mg} ; \mathrm{p}=0,0001)$ foi menor no grupo antagonista do $\mathrm{GnRH}$. O número de folículos ( $\geq 16 \mathrm{~mm}$ ) no dia da rhCG $(6,76$ vs. 4,$64 ; p=0,04)$ foi maior no GnRH-ag. Não houve diferenças nos outros parâmetros, no entanto, o número de oócitos recuperados (5,92 vs. 4,16; $\mathrm{p}=0,06$ ) foi maior no grupo do agonista do $\mathrm{GnRH}$, mas a taxa de fertilização $(49,1$ vs. $70,8 \% ; p=0,29)$ foi maior no antagonista do GnRH. As taxas de gravidez química e clínica foram semelhantes em ambos os grupos.

Conclusão: a estimulação ovariana controlada tem um papel importante na reprodução humana e sabe-se que, em pacientes normo-respondedoras, o primeiro ciclo de tratamento expõe a paciente a um risco de uma resposta baixa ou excessiva. Neste estudo GnRH-ag e GnRH-ant proporcionaram resultados comparáveis, mas no protocolo antagonista foi menor o período de estimulação.

Palavras-chave: GnRH agonista, GnRH antagonista, resposta ovariana normal, infertilidade.

\section{INTRODUCTION}

After the first success of the assisted reproductive techniques (ART), major advancements have been made in the treatment of infertility in the last thirty-five years. Despite this developments the ideal protocol is still controversial and the age is the most important prognostic factor for response to controlled ovarian stimulation (COS) and for pregnancy outcome (Daya, 2000; Cheung et al., 2005; Pu et al., 2011; Orvieto \& Patrizio, 2013). During the assisted reproduction event, an optimal hormonal profile may exist that could lead to follicular aspiration of fully competent oocytes. A wide variety of ovarian hyperstimulation and ovulation induction protocols have been developed, in which gonadotropin-realising hormone (GnRH) analogues (agonists or antagonists) are used in conjunction with gonadotropins to induce ovulation and consequently blocking the natural release of LH by the positive feedback of estradiol $\left(E_{2}\right)$ in the brain (Fauser et al., 2008; Al-Inany et al., 2011; Bodri et al., 2011).

GnRH agonist (GnRH-ag) long protocol has been a usual standard COS method since it was introduced in assisted reproduction in the late 1980's (Daya, 2000). However, suppression necessitates an increase in the dosage of gonadotropins and in the duration of treatment (Kim et al., 2011). GnRH antagonist (GnRH-ant) since the late 1990's been used as part of the therapeutic in the assisted reproduction (Bodri et al., 2011). The GnRH-ant acts by directly binding the $\mathrm{GnRH}$ receptors and block them in a competitive manner (Cheung et al., 2005). The development of GnRH-ant capable of blocking the pituitary receptors offered a new therapeutic option. Consequently, GnRH-ant reduces the dosage and length of the exogenous gonadotropin treatment.

Comparative studies between the two analogues have suggested that the use of antagonists is associated with a shorter duration of the ovulatory stimulus and a decreased incidence of ovarian hyperstimulation syndrome (OHSS); however, the rates of pregnancy and live birth do not appear to be significantly affected, depending on the type of GnRH analogue used (Fauser et al., 2008; Hayden, 2008; Firouzabadi et al., 2010; Griesinger et al., 2010; Pu et al., 2011; Maldonado et al., 2013; Orvieto \& Patrizio, 2013). Multiple follicular development is achieved by extending the period during which the concentration of FSH remains above the FSH threshold necessary to stimulate single-follicular growth. Studies about pharmacology have suggesting that the time lag between FSH administration and follicular growth was at least 4 days long (Yong et al., 2003; Xavier et al., 2005; Hsieh et al., 2008; Aygum \& Kahraman, 2010; Firouzabadi et al., 2010). Daily Fixed doses protocols of gonadotropins to compare efficacy of treatment like length, the total dose of gonadotropins, as well as the number of oocytes recovered are pitfalls because frequently are necessary to adjust doses during treatment.

The aim of this study was to compare the effect of using a short-term GnRH agonist protocol with the GnRH antagonist in ovarian stimulation with a fixed dose of recombinant $\mathrm{FSH}$, for assisted reproductive treatment in women with normal ovarian response undergoing their first in vitro fertilization (IVF) or intracytoplasmic sperm injection (ICSI) cycle.

\section{METHODS}

This was a retrospective comparative study performed at the Human Reproduction Laboratory of the Clinical Hospital of the Federal University of Goiás (LabRep-HCUFG) and approved by our Institutional Review Board (CEP/HC-UFG n007/2011).

Included in the study were women aged $\leq 40$ years undergoing their first IVF/ICSI cycle performed from January 2009 to December 2012; body mass index (BMI) between 19 and $30 \mathrm{~kg} / \mathrm{m}^{2}$; basal $\mathrm{FSH}<10 \mathrm{mIU} / \mathrm{mL}$; $\mathrm{E}_{2}$ level of $<60 \mathrm{pg} / \mathrm{mL}$; regular menses and both ovaries present. Patients with polycystic ovary syndrome or who received another type of controlled ovulation stimulation protocol were excluded. Patients with these criteria were allocated to one of the study groups according to the analogue used for the ovarian stimulation. Hormonal profiles (serum levels of basal FSH, LH, and $\mathrm{E}_{2}$ ) and the number of basal antral follicle in ultrasound were measured on the 2nd or 3rd day of menstruation in all patients. In order to synchronize the cycles, all the patients received oral contraceptives pill (Gynera ${ }^{\circledR}$; Bayer HealthCare Pharmaceuticals) before controlled ovarian stimulation.

\section{Ovarian stimulation}

1. GnRH-agonist group - short protocol or so-called "flare-up" ( $n=25)$

Women in this group received leuprolide acetate (Lupron ${ }^{\circledR} ;$ Abbott) at a dose of $1 \mathrm{mg} /$ day starting on day 1 of the cycle till the day of rhCG injection. The ovaries were then stimulated with dose of $150 \mathrm{IU} /$ day recombinant FSH (rFSH; follitropin alfa Gonal $\mathrm{F}^{\circledR}$; Serono) started on day 3 of the menstrual cycle, for a variable period according to each patient. Follicular development was monitored by transvaginal ultrasound.

2. GnRH-antagonist group $(n=25)$ (Figueiredo et al., 2013) Clomiphene citrate $(100 \mathrm{mg} /$ day $)$ was given during the 
cycle on days two through six. The ovaries were then stimulated with dose of $150 \mathrm{IU} /$ day recombinant $\mathrm{FSH}$ ( $\mathrm{rFSH}$; follitropin alfa Gonal $\mathrm{F}^{\circledR}$; Serono) started on day 3 of the menstrual cycle, for a variable period according to each patient. GnRH antagonist cetrorelix (Cetrotide ${ }^{\circledR}$. Serono) was started at a dose of $0.25 \mathrm{mg} /$ day during the late follicular phase when at least one follicle of $\geq 14$ $\mathrm{mm}$ was observed by ultrasound.

To induce the final oocyte maturation in both groups (GnRH-ag and GnRH-ant), $250 \mu \mathrm{g}$ of recombinant hCG (rhCG, Ovidrel ${ }^{\circledR}$; Serono) was injected to induce follicular maturation when one or more follicles reached a mean diameter of $\geq 18 \mathrm{~mm}$. Oocyte retrieval was performed 34 to 36 hours after rhCG injection by transvaginal aspiration under ultrasound guidance. Standard IVF or ICSI was applied as indicated. One to four embryos were transferred into the uterus on day 3 of culture under ultrasound guidance. The luteal phase was supported by transvaginal micronized progesterone $200 \mathrm{mg}$ three times per day (Uterogestan ${ }^{\circledR}$; Besins Iscovesco). A serum beta HCG measurement was ordered two weeks after embryo transfer. In case of positive pregnancy test result, an ultrasound was performed four weeks afterwards for confirm the clinical pregnancy by the presence of a gestational sac with fetal cardiac activity on ultrasound.

Demographic, clinical and laboratorial outcome parameters were compared between the two groups. Analysis of data was carried out using SPSS 20.0 statistical analysis software (Statistical Packages for the Social Sciences, USA). Descriptive statistics for continuous variables were reported as means \pm standard deviation (SD). Categorical variables were described using frequency distributions and are presented as frequency (\%). The Mann-Whitney U-test for independent samples was used as appropriate to compare continuous variables. The $\mathrm{x}^{2}$ test was used to compare categorical variables. A P value < 0.05 was considered to be statistically significant.

\section{RESULTS}

A total of 50 patients who underwent ART with both GnRH agonist and antagonist protocols were evaluated regarding cycle characteristics and treatment outcome. The overall mean age for women was $34.12 \pm 4.39$ years (range $23-40$ ) and BMI was $23.6 \pm 3.91 \mathrm{~kg} / \mathrm{m}^{2}$. The mean duration of infertility was $3.1 \pm 1.80$ years. The causes of infertility were tubal factor $(56.6 \%)$, endometriosis $(32.1 \%)$ and other cause of infertility $(11.3 \%)$. Basic demographic characteristics such as age, BMI, fertility characteristics and hormonal profiles were not significantly different $(p>0.05)$ between the groups. These data are summarized in Table 1.

The results of the ovarian stimulation are show in Table 2 . The stimulation days with rFSH $(p=0.0091)$, total doses of gonadotropins $(p<0.0001)$, days use and total doses of $\mathrm{GnRH}$ analogues was significantly higher in $\mathrm{GnRH}-$ agonist group ( $p<0.0001$ and $p=0.0001$, respectively). A total of 252 oocytes were obtained $(5.04 \pm 3.84$, range 1-23): 148 from the GnRH-ag group and 104 from the $\mathrm{GnRH}$-ant. Statistically significant difference was found between the two stimulation protocols for the number of follicles ( $\geq 16 \mathrm{~mm}$ ) on day rhCG, considerably higher in GnRH-ag group $(p=0.04)$. However, oocytes retrieved, in MII, with 2PN, cleaved and transferred embryos were similar between the groups (show in Table 2). No cycle was cancelled before oocyte retrieval because of premature LH surge in this study, so all patients had oocyte retrieval, and no patients developed ovarian hyperstimulation syndrome (OHSS).

\section{DISCUSSION}

The present study evaluated the results of GnRH agonist (leuprolide short protocol) compared with GnRH antagonist (cetrorelix); using dose of $150 \mathrm{IU} /$ day rFSH (follitropin alfa) for ovarian stimulation, in Brazilian normoresponder patients undergoing their first IVF/ICSI cycle. There is a debate regarding the best stimulation protocol
Table 1. Characteristics for patients who received different protocols of gonadotropin-releasing hormone (GnRH) for pituitary suppression during controlled ovarian stimulation. LabRep-HC-UFG, 2012.

\begin{tabular}{|c|c|c|c|}
\hline & Agonist & Antagonist & $\boldsymbol{P}$ \\
\hline \multicolumn{4}{|l|}{$\begin{array}{l}\text { Physical } \\
\text { characteristics }\end{array}$} \\
\hline Cycles analyzed & 25 & 25 & \\
\hline Age (years) & $33.76 \pm 4.30$ & $34.48 \pm 4.54$ & $0.46^{c}$ \\
\hline BMI $\left(\mathrm{Kg} / \mathrm{m}^{2}\right)$ & $24.30 \pm 2.90$ & $23.50 \pm 2.70$ & $0.86^{c}$ \\
\hline \multicolumn{4}{|l|}{$\begin{array}{l}\text { Fertility } \\
\text { characteristics }\end{array}$} \\
\hline $\begin{array}{l}\text { Duration infertility } \\
\text { (years) }\end{array}$ & $3.3 \pm 1.60$ & $3.0 \pm 1.20$ & $0.53^{c}$ \\
\hline Infertility & & & $0.37^{d}$ \\
\hline Primary & $44 \%(11)$ & $28 \%(07)$ & \\
\hline Secondary & $56 \%(14)$ & $72 \%(18)$ & \\
\hline Aetiology & & & $0.9^{d}$ \\
\hline Tubal factor & $52 \%(13)$ & $60 \%(15)$ & \\
\hline Endometriosis & $48 \%(12)$ & $20 \%(05)$ & \\
\hline Other cause & $0 \%(0)$ & $20 \%(05)$ & \\
\hline \multicolumn{4}{|l|}{$\begin{array}{l}\text { Basal female } \\
\text { hormonal a }^{\text {a }}\end{array}$} \\
\hline $\mathrm{FSH}(\mathrm{mUI} / \mathrm{mL})$ & $6.04 \pm 2.13$ & $5.53 \pm 1.45$ & $0.34^{c}$ \\
\hline $\mathrm{LH}(\mathrm{mUI} / \mathrm{mL})$ & $3.44 \pm 1.46$ & $3.68 \pm 1.50$ & $0.79^{c}$ \\
\hline Estradiol $(\mathrm{pg} / \mathrm{mL})$ & $37.35 \pm 25.23$ & $58.06 \pm 58.17$ & $0.12^{c}$ \\
\hline Antral follicle count ${ }^{b}$ & $4.37 \pm 3.60$ & $4.81 \pm 2.60$ & $0.59^{c}$ \\
\hline $\begin{array}{l}\text { on cycle day } 3 \\
\geq 3 \text { follicles } \\
\text { Mann-Whitney } \\
x 2 \text { test }\end{array}$ & & & \\
\hline
\end{tabular}

which should be the first choice in a normoresponder woman. The statistically significant differences observed in the number of stimulation days with rFSH, total doses of gonadotropins, days use and total doses of $\mathrm{GnRH}$, and the number of follicles ( $\geq 16 \mathrm{~mm}$ ) on day rhCG were higher in $\mathrm{GnRH}-\mathrm{ag}$ group.

Yong et al., (2003) was the first comparative study of two different doses of the rFSH (Gonal- ${ }^{\circledR}$ ) in a fixed-dose regime and their results show a dose-dependent increase in ovarian response to COS, as evidenced by the degree of follicular recruitment and the number of oocytes retrieved. This was achieved with a shorter duration of stimulation, but at the expense of an increased total rFSH dose. We used a daily fixed dose of rFSH in this study and found that the $\mathrm{GnRH}-\mathrm{ag}$ group required more days of use increasing the total dosage used of the gonadotropin.

Cochrane review (Van Wely et al., 2003) and Hompes et al., (2008) propose the importance of use more uniform procedures, such as a fixed gonadotropin dosage to minimizes the variability. This is especially important in studies where investigators theoretically could introduce a bias by selectively adapting the dosage of gonadotropin. On the other hand, a strict fixed dose also has disadvantages and could may not be ideal for evaluating pregnancy rates where the outcomes would conditioned by the proportion of patients who responded to the dose selected (Hompes et al., 2008). 
Human reproduction centers use oral contraceptive pill (OCP) to schedule the patients to meet the organizational needs with practical implications. Griesinger et al., (2008) in a systematic review and meta-analysis summarizes data from four randomized clinical trials on OCP pretreatment in ovarian stimulation for IVF to schedule the start of gonadotropin stimulation using $\mathrm{GnRH}$ antagonists showed that the consumption of gonadotropins and the duration of ovarian stimulation was significantly increased after OCP pretreatment.

We also observed that the stimulation days increased in the GnRH agonist group, but the total dose of the gonadotropin, consequently, also increased in the same group. Furthermore, it is evident that the use of OCP will increase the overall treatment duration and the total financial cost. These drawbacks should to be observed by clinicians and patients considering the benefits associated with treatment scheduling.

Xavier et al., (2005) in Portuguese women without OCP, showed statistically significant differences only two parameters: the duration of stimulation (using 150-450 $\mathrm{IU} /$ day $\mathrm{rFSH}$ ) and the duration of suppression in the agonist group (using $0.6 \mathrm{mg}$ of busereline long protocol). However, the total dose of the rFSH was higher in the antagonist group (with $0.25 \mathrm{mg}$ cetrorelix) and the number of follicles ( $\geq 15 \mathrm{~mm}$ ) on day hCG were higher in GnRH agonist group, but no was difference statistically significant. We also observe that the total dose increased in the GnRH-ag group, but using a fixed dose of rFSH. Hsieh et al., (2008) in Asian normoresponder patients, compared different dosage protocols for cetrorelix $(0.25,0.2$ and $0.15 \mathrm{mg} /$ day), leuprolide $(0.5 \mathrm{mg} /$ day long protocol) and leuprolide depot (1.88 $\mathrm{mg}$ ) with rFSH (follitropin alfa) 150-225 IU/day in younger patients ( $<34$ years) and in older patients ( $\geq 34-39$ years) were administered 225-300 IU/day; without the use of OCP. These authors verified that the number of oocytes retrieved was higher in group with $0.25 \mathrm{mg}$ cetrorelix than those in other groups and also produced better qualities of embryos and oocytes.

Current consensus is that a higher dose leads to the retrieval of more oocytes but similar pregnancy rates in standard patients (younger than 40 years of age, having two ovaries, a normal menstrual cycle and a normal basal FSH level) (Fauser et al., 2008; Hayden, 2008). Firouzabadi et al., (2010) recommended dose of rFSH was 100 to $250 \mathrm{IU} /$ day in the agonist protocol and 150 or $200 \mathrm{IU} /$ day in the GnRH antagonist cycles.

Kolibianakis et al., (2006) propose that the stimulation duration was shorter and there was less usage of rFSH used GnRH antagonist protocol as an advantage when compared with agonist treatment, and Huang et al., (2011) showed some advantages of the GnRH antagonist protocol. Aygun \& Kahraman, (2010) concluded that GnRH antagonist (using $0.25 \mathrm{mg}$ cetrorelix) protocol might be considered as comparable and even better compared with agonist (using $0.5 \mathrm{mg}$ leuprolide long protocol) in a Turkish normoresponder woman. Therefore, they suggest that in patients in the first attempt, the other one might be considered safely for the next treatment cycle instead of giving the same protocol again. The result of the studies of Tehraninejad et al., (2011) reported that duration of stimulation days was significantly longer in agonist group, using starting dose 150-225 IU/day rFSH in Iranian normoresponder patients. This same study showed greater number of MII oocyte in agonist group.

We not found a study with same protocols of this (leuprolide short protocol or cetrorelix GnRH analogue and follitropin alfa rFSH daily fixed dose). In our observation the antagonist protocol resulted in a reduction in the duration of stimulations days with rFSH and diminish the amount of gonadotropin administered. This shortened the duration of GnRH analogue therapy, when compared with $\mathrm{GnRH}$-ag protocol. Many studies showed that it is more patient-friendly protocol because patients are likely to prefer shorter cycles with reduced number of injec-
Table 2. Controlled ovarian stimulation and laboratory outcomes for patients who received different protocols of gonadotropin-releasing hormone (GnRH) for pituitary suppression during controlled ovarian stimulation. LabRep-HC-UFG, 2012.

\begin{tabular}{|c|c|c|c|}
\hline & Agonist & $\begin{array}{l}\text { Antago- } \\
\text { nist }\end{array}$ & $\boldsymbol{P}$ \\
\hline \multicolumn{4}{|l|}{ Ovarian stimulation } \\
\hline $\begin{array}{l}\text { Days of rFSH } \\
\text { (150 IU/day) }\end{array}$ & $11.0 \pm 1.77$ & $\begin{array}{l}9.24 \pm \\
2.22\end{array}$ & 0.0091 a* \\
\hline $\begin{array}{l}\text { Total dose of rFSH } \\
\text { required (IU) }\end{array}$ & $\begin{array}{l}2094 \pm \\
352.39\end{array}$ & $\begin{array}{l}1365 \pm \\
293.68\end{array}$ & $<0.0001$ a* \\
\hline \multicolumn{4}{|l|}{$\begin{array}{l}\text { Pituitary down- } \\
\text { regulation }\end{array}$} \\
\hline $\begin{array}{l}\text { Duration of suppression } \\
\text { (days) }\end{array}$ & $12 \pm 1.63$ & $\begin{array}{c}3.60 \pm \\
1.22 \\
\end{array}$ & $<0.0001$ a* \\
\hline Total dose of GnRH (mg) & $1.2 \pm 0.16$ & $\begin{array}{c}0.90 \pm \\
0.30\end{array}$ & 0.0001 a* \\
\hline \multicolumn{4}{|l|}{ Clinical outcomes } \\
\hline $\begin{array}{l}\text { Follicles } \geq 16 \mathrm{~mm} \\
\text { (rhCG day) }\end{array}$ & $6.76 \pm 4.57$ & $\begin{array}{c}4.64 \pm \\
3.21\end{array}$ & 0.04 a* \\
\hline \multicolumn{4}{|l|}{ Laboratory outcomes } \\
\hline Oocytes retrieved & $5.92 \pm 4.58$ & $\begin{array}{c}4.16 \pm \\
2.76 \\
\end{array}$ & $0.06^{a}$ \\
\hline MII oocytes & $4.48 \pm 4.02$ & $\begin{array}{c}3.16 \pm \\
2.21\end{array}$ & $0.27^{a}$ \\
\hline 2PN oocytes & $2.20 \pm 2.08$ & $\begin{array}{c}2.24 \pm \\
2.31\end{array}$ & $0.91^{a}$ \\
\hline Embryos cleaved & $2.04 \pm 2.0$ & $\begin{array}{c}2.16 \pm \\
2.24\end{array}$ & $0.94^{a}$ \\
\hline $\begin{array}{l}\text { Embryos transferred } \\
\text { (day 3) }\end{array}$ & $1.80 \pm 1.29$ & $\begin{array}{c}1.72 \pm \\
1.40\end{array}$ & $0.83^{a}$ \\
\hline Fertilization rate & $\begin{array}{c}40.1 \% \\
(45 / 112)\end{array}$ & $\begin{array}{r}54.4 \% \\
(43 / 79)\end{array}$ & $0.29^{b}$ \\
\hline Implantation rate & $\begin{array}{l}13.3 \% \\
(06 / 45) \\
\end{array}$ & $\begin{array}{c}9.3 \% \\
(04 / 43)\end{array}$ & $0.42^{b}$ \\
\hline Pregnancy per cycle & $\begin{array}{c}24 \% \\
(06 / 25)\end{array}$ & $\begin{array}{c}16 \% \\
(04 / 25) \\
\end{array}$ & $0.41^{b}$ \\
\hline Miscarriages & $\begin{array}{c}10 \% \\
(01 / 10) \\
\end{array}$ & $\begin{array}{c}20 \% \\
(02 / 10) \\
\end{array}$ & $0.53^{b}$ \\
\hline $\begin{array}{l}\text { a Mann-Whitney } \\
{ }^{\circ} \times 2 \text { test } \\
\text { MII - metaphase II } \\
\text { 2PN - two pronucleus } \\
\text { Values expressed as mear }\end{array}$ & $\mathrm{CD}^{\circ}$ & ber) & \\
\hline
\end{tabular}

tions and side effects among other benefits (Xavier et al., 2005; Younis et al., 2010; Orvieto \& Patrizio, 2013). Hsieh et al., (2008) demonstrated that GnRH antagonist protocol was effective, although a slight reduction in pregnancy rate may be rectified by developing flexible regimens designed for individual patients. The corpus luteum function seems to be impaired with GnRH antagonist. However, is associated with elevated progesterone levels in the late follicular phase and accelerated endometrial maturation in the subsequent luteal phase. Maldonado et a., (2013) also observed that duration of $\mathrm{GnRH}$ was significantly reduced the mean number of injections from 20 to 6.6 compared with the long agonist schedule. These authors showed that down-regulation with a $\mathrm{GnRH}$-ag (tryptorelin $0.1 \mathrm{mg}$ ) on alternate days is significantly less costly than the GnRH-ant treatment, in Brazilian normal-responding patients stimulated with rFSH (starting 225 IU/day) and rhCG microdoses.

In this study there was no difference in the oocytes retrieved, MII oocytes, 2PN oocytes, and cleaved and transferred embryos. Though higher, the number oocytes retrieved in $\mathrm{GnRH}-\mathrm{ag}$ group was not significant, but the 
fertilization rate was higher in $\mathrm{GnRH}$-ant group, nevertheless with more miscarriages. The rates of chemical and clinical pregnancy were similar in two groups. The rate of abortion was bigger in $\mathrm{GnRH}$-ant group, but this was not statistically significant in present study. Bahceci et al., 2009 reported that the rate of early pregnancy loss was higher in antagonist protocol.

After a decade of doubts and hesitation, GnRH antagonist protocols have become extremely popular and are widely used during COS (Bahceci et al., 2009; Devroey et al., 2009; Younis et al., 2010; Huang et al., 2011; Kim et al., 2011; Tehraninejad et al., 2011). A recent Cochrane review meta-analysis (Al-Inany et al., 2011), which was comparing $\mathrm{GnRH}$ antagonist versus the long agonist protocol has apparently settled the ongoing debate on the place of $\mathrm{GnRH}$ antagonists in infertility treatment. Johnston-MacAnanny et al. (2011), in a retrospective review of patients undergoing their first IVF cycle and good responders, showed that clinical and ongoing pregnancy rates and implantation rates were similar in 755 patients in $\mathrm{GnRH}$ agonist and 378 in a GnRH antagonist protocol. Orvieto \& Patrizio, (2013) reported that multiple meta-analyses comparing $\mathrm{GnRH}$ agonist long with $\mathrm{GnRH}$ antagonist protocols have yielded conflicting results for pregnancy rate and argues that the equivalence of these two protocols is not as clear as it has been presented. Controlled ovarian stimulation plays a major role in reproductive medicine and represents a fundamental step on the way to a pregnancy using assisted reproductive techniques. In conventional ovarian stimulation for IVF/ICSI, it is well known that, even in normoresponders patients, the first treatment cycle exposes patients to a risk of either a low or an excessive ovarian response. Our data indicates that $\mathrm{GnRH}-\mathrm{ag}$ short protocol appears to be slightly more effective than the $\mathrm{GnRH}$-ant protocol, but shows statistically no significant difference in pregnancy rate.

GnRH antagonists provide significant advantages in terms of fewer injections, fewer days, and avoidance of the adverse effects of the agonist, including an immediate mode of action, flexibility of use and reversibility of action as soon as the analogue is discontinued, making the antagonist protocols an attractive modern approach for ovarian stimulation and probably the analogue of first choice for pituitary down-regulation (Copperman \& Benadiva, 2013).

In conclusion, a shorter duration of rFSH stimulation and administration of $\mathrm{GnRH}$-ant (with a lower probability of OHSS), and an insignificant difference in the rate of live births compared with GnRH-ag. The retrospective design of the study prevents us from drawing firm conclusions regarding the effect of GnRH analogues in normoresponders. Further more studies, as well as randomized clinical trials, are required to knowledge of the better protocol for to use in normoresponder women undergoing ART.

\section{Corresponding Author}

Laboratório de Reprodução Humana, Hospital das Clínicas, Departamento de Ginecologia e Obstetrícia, Faculdade de Medicina da Universidade Federal de Goiás

$1^{a}$ Avenida, $s / n$, Setor Universitário

CEP: 74605-020 - Goiânia - GO - Brasil

Tel.: (62) 3269-8278

E-mail: jalsitacon@gmail.com

\section{REFERENCES}

Al-Inany HG, Youssef MA, Aboulghar M, Broekmans F, Sterrenburg M, Smit J, Abou-Setta AM. Gonadotropin-releasing hormone antagonists for assisted reproductive technology. Cochrane Database Syst Rev 2011;(5):CD001750.

Aygum BK, Kahraman S. Comparison of GnRH agonist long and antagonist protocols in the same normoresponders patient undergoing assisted reproductive treatment. Firat Tıp Dergisi 2010;15(3):123-27.
Bahceci M, Ulug U, Sismanoglu A, Tosun S, Cengiz B. Early pregnancy loss rate were different among singleton gestations conceived by ICSI using GnRH agonist and antagonist. J Asist Reprod Genet 2009;26(4):227-29.

Bodri D, Sunkara SK, Coomarasamy A. Gonadotropin-releasing hormone agonists versus antagonists for controlled ovarian hyperstimulation in oocyte donors: a systematic review and meta-analysis. Fertil Steril 2011;95(1):164-69.

Cheung LP, Lam PM, Lok IH, Chiu TT, Yeung SY, Tjer CC, Haines CJ. GnRH antagonist versus long $\mathrm{GnRH}$ agonist protocol in poor responders undergoing IVF: a randomized controlled trial. Hum Reprod 2005;20(3):616-21.

Copperman AB, Benadiva C. Optimal usage of the $\mathrm{GnRH}$ antagonists: a review of the literature. Reprod Biol Endocrinol 2013;11:20.

Daya S. Gonadotropin releasing hormone agonist protocols for pituitary desensitization in in vitro fertilization and gamete intrafallopian transfer cycles. Cochrane Database Syst Rev 2000;(2):CD001299.

Devroey P, Aboulghar M, Garcia-Velasco J, Griesinger G, Humaidan $\mathrm{P}$, Kolibianakis E, Ledger W, Tomás C, Fauser BC. Improving the patient's experience of IVF/ICSI: a proposal for an ovarian stimulation protocol with $\mathrm{GnRH}$ antagonist co-treatment. Hum Reprod 2009;24(4):764-74.

Fauser BC, Diedrich K, Devroey P, Evian Annual Reproduction Workshop Group 2007. Predictors of ovarian response: progress towards individualized treatment in ovulation induction and ovarian stimulation. Hum Reprod Update 2008;14(1):1-14.

Figueiredo JBP, Nastri CO, Vieira ADD, Martins WP. Clomiphene combined with gonadotropins and $\mathrm{GnRH}$ antagonist versus conventional controlled ovarian hyperstimulation without clomiphene in women undergoing assisted reproductive techniques: systematic review and meta-analysis. Arch Gynecol Obstet 2013;287(4):779-90.

Firouzabadi RD, Ahmadi S, Oskouian H, Davar R. Comparing GnRH agonist long protocol and GnRH antagonist proto$\mathrm{col}$ in outcome the first cycle of ART. Arch Gynecol Obstet 2010;281(1):81-85.

Griesinger G, Kolibianakis EM, Venetis C, Diedrich K, Tarlatzis B: Oral contraceptive pretreatment significantly reduces ongoing pregnancy likelihood in gonadotropin releasing hormone antagonist cycles: an updated meta-analysis. Fertil Steril 2010, 94:2382-2384.

Griesinger G, Venetis CA, Marx T, Diedrich K, Tarlatzis BC, Kolibianakis EM. Oral contraceptive pill pretreatment in ovarian stimulation with $\mathrm{GnRH}$ antagonists for IVF: a systematic review and meta-analysis. Fertil Steril 2008;90(4):1055-63.

Hayden C. GnRH analogues: applications in assisted reproductive techniques. Eur J Endocrinol 2008;(159 Suppl 1):S17-25.

Hompes PG, Broekmans FJ, Hoozemans DA, Schats R, FIRM group. Effectiveness of highly purified human menopausal gonadotropin vs. recombinant follicle-stimulating hormone in first-cycle in vitro fertilization-intracytoplasmic sperm injection patients. Fertil Steril 2008;89(6):1685-93.

Hsieh YY, Chang CC, Tsai HD. Comparisons of different dosages of gonadotropin-releasing hormone ( $\mathrm{GnRH}$ ) antagonist, short-acting form and single, half-dose, long-acting form of $\mathrm{GnRH}$ agonist during controlled ovarian hyperstimulation and in vitro fertilization. Taiwan J Obstet Gynecol 2008; 47(1):66-74.

Huang SY, Huang HY, Yu HT, Wang HS, Chen CK, Lee CL, Soong YK. Low-dose GnRH antagonist protocol is as effective as the long GnRH agonist protocol in unselected patients undergoing in vitro fertilization and embryo transfer. Taiwan J Obstet Gynecol 2011;50(4):432-35.

Johnston-MacAnanny EB, DiLuigi AJ, Engmann LL, Maier DB, Benadiva CA, Nulsen JC. Selection of first in vitro fertilization cycle stimulation protocol for good prognosis patients: gonadotropin releasing hormone antagonist versus agonist protocols. J Reprod Med 2011;56(1-2):12-16.

Kim CH, You RM, Kang HJ, Ahn JW, Jeon I, Lee JW, Kim SH, Chae HD, Kang BM. GnRH antagonist multiple dose protocol with oral contraceptive pill pretreatment in poor responders undergoing IVF/ICSI. Clin Exp Reprod Med 2011;38(4):228-33. 
Kolibianakis EM, Collins J, Tarlatzis BC, Devroey P, Diedrich K, Griesinger G. Among patients treated for IVF with gonadotrophins and $\mathrm{GnRH}$-analogues, is the probability of live birth dependent on the type of analogue used? A systematic review and meta-analysis. Hum Reprod Update 2006;12(6):651-71.

Maldonado LG, Franco Jr JG, Setti AS, Iaconelli Jr A, Borges Jr E. Cost-effectiveness comparison between pituitary down-regulation with gonadotropin-releasing hormone agonist short regimen on alternate days and an antagonist protocol for assisted fertilization treatments. Fertil Steril 2013;99(6):1615-22.

Orvieto R, Patrizio P. GnRH agonist versus $\mathrm{GnRH}$ antagonist in ovarian stimulation: an ongoing debate. Reprod Biomed Online $2013 ; 26(1): 4-8$.

$\mathrm{Pu}$ D, Wu J, Liu J. Comparisons of GnRH antagonist versus GnRH agonist protocol in poor ovarian responders undergoing IVF. Hum Reprod 2011;26(10):2742-49.

Tehraninejad E, Nezamabadi AG, Rashidi B, Sohrabi M, Bagheri M, Haghollahi F, Nekoo EA, Jafarabadi M. GnRH antagonist versus agonist in normoresponders undergoing ICSI: a randomized clinical trial in Iran. Iran J Reprod Med 2011;9(3):171-76.
Van Wely M, Westergaard LG, Bossuyt PM, Van der Veen F. Human menopausal gonadotropin versus recombinant follicle stimulation hormone for ovarian stimulation in assisted reproductive cycles. Cochrane Database Syst Rev 2003; (1):CD003973.

Xavier P, Gamboa C, Calejo L, Silva J, Stevenson D, Nunes A, Martinez-de-Oliveira J. A randomised study of $\mathrm{GnRH}$ antagonist (cetrorelix) versus agonist (busereline) for controlled ovarian stimulation: effect on safety and efficacy. Eur J Obstet Gynecol Reprod Biol 2005;120(2):185-89.

Yong PY, Brett S, Baird DT, Thong KJ. A prospective randomized clinical trial comparing 150 IU and 225 IU of recombinant follicle-stimulating hormone (Gonal- $\mathrm{F}^{\circledR}$ ) in a fixed-dose regimen for controlled ovarian stimulation in in vitro fertilization treatment. Fertil Steril 2003;79(20):308-15.

Younis JS, Soltsman S, Izhaki I, Radin O, Bar-Ami S, Ben-Ami M. Early and short follicular gonadotropin-releasing hormone antagonist supplementation improves the meiotic status and competence of retrieved oocytes in in vitro fertilizationembryo transfer cycles. Fertil Steril 2010;94(4):1350-55. 